\title{
Brown-Séquard, a restless mind
}

\author{
Brown-Séquard, uma mente inquieta
}

Eliasz Engelhardt' ${ }^{1}$ Marleide da Mota Gomes ${ }^{2}$

\begin{abstract}
Brown-Séquard, a remarkable medical personality of the $19^{\text {th }}$ century, was born in a small island of the Indian Ocean. He travelled over the world exerting his skills: a successful physician, and an innovative researcher, with a very ample range of interests. His favored subject was the nervous system. The spinal cord was studied extensively, with novel and important discoveries on the sensory pathways. He identified cases with spinal cord hemisection, and described the clinical presentation corresponding to a syndrome which bears his name (BrownSéquard syndrome), for which he is best known among neurologists. Regarding the brain, he proposed nine mental and physical functions (organs) related to dynamically interconnected cell clusters, in harmony with the "réseau de cellules anastomosées", "activités dynamogeniques et inhibitrices", and "action à distance" concepts. Finally, he is considered by some as the "father" of endocrinology, due to his studies on glands and their secretions.
\end{abstract}

Keywords: hemisection of the spinal cord, Brown-Séquard syndrome, net of anastomosed cells, facilitatory and inhibitory activity, action at distance.

\section{RESUMO}

Brown-Séquard, notável personalidade médica do século 19, nasceu em uma pequena ilha do Oceano Índico. Viajou pelo mundo exercendo suas habilidades: médico de sucesso e pesquisador ousado, com gama muito extensa de interesses. Seu assunto favorito era o sistema nervoso. A medula foi estudada de modo amplo, com descobertas novas e importantes sobre as vias sensitivas. Identificou casos com hemisseção medular e descreveu o quadro clínico correspondente a uma síndrome que leva seu nome (síndrome de Brown-Séquard), motivo pelo qual é melhor conhecido entre os neurologistas. Considerando o cérebro, propôs nove funções (órgãos) mentais e físicas relacionadas de modo dinâmico a conglomerados celulares, em harmonia com seus conceitos de "réseau de cellules anastomosées", “activités dynamogeniques et inhibitrices" e "action à distance". Finalmente, ele é considerado por alguns como "pai" da endocrinologia, devido seus estudos sobre glândulas e suas secreções.

Palavras-chave: hemisseção da medula, síndrome de Brown-Séquard, rede de células anastomosadas, atividade facilitadora e inibidora, ação à distância.

Charles Édouard Brown-Séquard (1817-1894) was born at Port Louis, in the British Mauritius Island (formerly the French Île de France, and presently Republic of Mauritius, since 1968), in the Indian Ocean. Originally Charles Édouard Brown, he changed his name by adding his mother's maiden one to his own, after her death, in 1842. The baccalaureate and doctoral degrees were completed at the School of Medicine (Paris) in 1846. He was a physiologists and exerted clinical Medicine, mainly in the neurological field ${ }^{1,2}$.

\section{IN SEARCH OF A NICHE - THE WANDERER}

Brown-Séquard's education and medical training were French, but as the Île de France had become part of the British Empire a few years before his birth, he was a British citizen, ineligible for a lasting position in a French institution. This may explain, partly at least, his peregrinations, that begun in 1852, reinforced by political reasons (after Bonaparte's coup d'état, and he was a Republican opponent). He searched

\footnotetext{
${ }^{1}$ Neurologist, Full Professor (retired), Setor de Neurologia Cognitiva e do Comportamento, Instituto de Neurologia Deolindo Couto, Centro para Doença de Alzheimer, Instituto de Psiquiatria, Universidade Federal do Rio de Janeiro, Rio de Janeiro RJ, Brazil;

${ }^{2}$ Neurologist, Associate Professor, Programa de Epilepsia, Instituto de Neurologia Deolindo Couto, Instituto de Psiquiatria, Universidade Federal do Rio de Janeiro, Rio de Janeiro RJ, Brazil.

Correspondence: Eliasz Engelhardt;Av. N.S. Copacabana 749/708;22050-002 Rio de Janeiro RJ - Brasil; E-mail: eliasz@centroin.com.br

Conflict of interest: There is no conflict of interest to declare.

Received 22 April 2013; Received in final form 09 September 2013; Accepted 16 September 2013.
} 
for a niche, a professional position that would satisfy him, in an indefatigable way. He navigated in the Indian and Atlantic oceans, the latter he crossed about 60 times, spending almost 6 years on the sea. He lived and worked in several places, in Mauritius, France, United States, Great Britain, always achieving great professional success and ample recognition. Finally he settled in Paris where he accepted, after Claude Bernard death, the vacant professorship of Experimental Medicine at the Collége de France. He held this position until the end of his life ${ }^{1,3}$.

\section{RESEARCH - NERVOUS SYSTEM, GLANDS, AND OTHER ISSUES}

Brown-Séquard was a profound observer and experimentalist. His investigations, some of them far from orthodox, were performed on a diversisity of animals, some of them exotic in research. The used techniques were mostley based on vivisection, lesion, galvanization, organ removal, extracts injection (including in himself), among others. His contributions ranged several areas: (i) physiology and pathology of the nervous system; (ii) research on epilepsy; (iii) general and special physiology; (iv) animal heat; (v) physiology and pathology of the eye and vision; (vi) miscellaneous, isolated experiments intermingled with ongoing studies, and (vii) varied issues in physiology and medicine ${ }^{4}$, remaining very productive till the end of his time. The nervous system was especially privileged by his interest, with numerous studies on the peripheral (including the autonomic) and central divisions. He also laid a strong focus on glands and secretions, an emergent field he helped to build up. He was recognized, by some, as the "father" of Endocrinology $y^{1,3}$.

Some particular aspects of Brown-Séquard's studies on the spinal cord and brain merit a closer look.

\section{SPINAL CORD}

His contribution to the understanding of the physiology and pathology of the spinal cord was extensive. His first work, on sensory paths and reflex action of the spinal cord, constituted his Doctorate Thesis (Recherches et experiences sur la physiologie de la moelle épinière). Further studies on this subject demonstrated that the sensory paths relaying pain and temperature sensation cross at the level of the spinal cord, while those that carry muscular sense do not, ascending uncrossed to higher levels ${ }^{5}$. He identified cases presenting hemisection of the spinal cord, described as follows: "Facts proving that a lesion in one of the lateral halves of the spinal cord produces (i) paralysis of voluntary movements in the same side, (ii) anaesthesia to touch, tickling, painful impressions, and changes of temperature in the opposite side, (iii) paralysis of the muscular sense in the same side"6. This clinical presentation corresponds to a syndrome which bears his name (Brown-Séquard syndrome), for which he is mostly known among neurologists.

\section{BRAIN: CEREBRAL LOCALIZATION AND NEURAL NETWORKS}

Brown-Séquard's strong interest on brain functions was very fruitful. At the time, many physiologists and clinicians advocated that most of the functions of the brain were related to their centers (or organs), distinct and well defined clusters of cells and fibers where most functions were localized, constituting a "theory of centers". Famous personalities, as Hitzig, Ferrier, Charcot, among others defended such theory ${ }^{1,7,8}$. In opposition, Brown-Séquard repelled such localizationist theory. His anti-localizationism, underpinned by some of his points of view, possibly influenced personalities such as Goltz, Jackson, von Monakow, and Sherrington ${ }^{1,7}$.

The brain (encephalon), as he proposed, exerted nine mental and physical functions: (i) intelligence, (ii) consciousness, (iii) faculties of expressing ideas, speech writing, and gesture, (iv) memory, (v) vision, audition, olfaction, taste, touch, and general sensibility, (vi) muscular sense, (vii) voluntary movements, (viii) respiratory movements, (ix) deglutition, related to the activity of distinct disseminated neuron clusters (organs) dynamically interconnected ${ }^{9,10,8}$. He argued for the existence of nervous elements disseminated in many parts of the brain forming a network of anastomosing cells - the concept of a "réseau de cellules anastomosées" ${ }^{\text {, where }}$ the "nerve-cells possessing the same functions must communicate with each other, and such communications are essential, and that concerted and harmonious actions can take place by means of intervening fibers exactly as well between distant as between neighboring nerve-cells" ${ }^{7,9,10}$. His conviction was that the functioning of these structures was under the influence of "activités dynamogeniques et inhibitrices" (facilitatory and inhibitory activities) ${ }^{9}$. In his view a lesion of one part of an organ could temporarily inhibit elements of another distant one ("action à distance"), and the release of the inhibition of these undamaged distant elements may result in recovery ${ }^{8,9,10}$. He explained how lesions in many different parts of one cerebral hemisphere could produce the similar kinds of paralysis, by "some peculiar influence exerted at a distance from some parts of the cerebral lobes on the active lower parts of the brain"1,2,9,10.

These concepts and points of view may be viewed as ahead of his time, and antedated the neural network functional characteristic of the brain, widely accepted in the present days, and certainly representing precursor announcements of von Monakow's theories, including 
the"diaschisis" concept, and of the Jacksonian thoughts on "evolutionary hierarchy".

In conclusion, Brown-Séquard was a complex personality (Box) and a very active person, interested in a ample assortment of subjects. He engaged in varied experiments on a diversisity of animals, using the numerous techniques available at the time. As a clinician, he was renowned and successful, exerting his medical skills mainly as a neurologist, and in this domain, besides treating his patients, he used the opportunity for clinical research.

Reading a number of Brown-Séquard's writings, and of those that were published about him, it is possible to perceive his remarkable personality. He was a hard working man and persistently pursued his ideas in search for their comprovation. Some of his ideas might seem not valid, sometimes based on imprecise observations, with a frequent intuitive approach, and an apparently tortuous reasoning. However, it is not possible to deny his insight power and his insistence to resolve clinical problems through experimental work on animals.

His courage to express his thoughts and findings, and support them even when attacked by powerful scientific opponents, must be praised.

The legacy he left is in the form of hundreds of texts, among books, lectures, conferences, papers, communications, discussions. This production was not linear, in the same way as his life, and he recurred on the themes he studied over decades, in a repetitive way. However, each of his releases always showed some difference in the focus or in the conclusion, apparently sculpturing ideas he tracked. At first sight it might seem confusing, but looking closer at his work as a whole, it is possible, at least in relation to his main themes, to recognize this material as a puzzle that must be assembled or a patchwork that must be sewed. Some pieces do not fit or are not consistent or are discarded, but it resembles a work in transition, in the direction of a thought he pursued.

It is not possible to describe Brown-Séquard's life and deeds in a short way, a life full of scientific and clinical happenings. Thus, it is necessary to cite some of the most talented and inspiring medical historians dedicated to analyze and comment on the oeuvre of this amazing personality, such as Aminoff, Bonduelle, Bowditch, Cussons, Dunbar, Éloy, Finger, Goetz, Gooddy, Goodrich, Jefferson, Kahn, Koehler, Laporte, Pearce, Rengachary, Ruch, Tattersall, Wilson, York, among others.

Box. Brown-Séquard's creative, tenacious, and productive personality 1,2,7,

\section{References}

1. Aminoff MJ. Brown-Séquard: selected contributions of a nineteenthcentury neuroscientist. Neuroscientist 2000;6:60-65.

2. Laporte Y. Charles-Edouard Brown-Séquard. An eventful life and a significant contribution to the study of the nervous system. CR Soc Biol 2006;329:363-368.

3. Wilson JD. Charles-Edouard Brown-Séquard and the centennial of endocrinology. J Clin Endocrinol Metabol 1990;71:1403-1409.

4. LBM. Libraire de l'Académie de Médicine. Brown-Séquard CE. Notice sur les travaux scientifiques du Docteur CE Brown-Séquard. Paris:Masson, 1886. (Retrieved from: http://web2.bium.univ-paris5. $\mathrm{fr} /$ livanc/?cote $=110133 \times 131 \times 01 \&$ do $=$ chapitre)

5. Brown-Séquard CE. Course of lectures on the physiology and pathology of the central nervous system (delivered at the Royal
College of Surgeons of England in 1858). Philadelphia: Collins, Printer, 1860:18-111. (Retrieved from: http://archive.org/details/ courseoflectures00brow)

6. Brown-Séquard CE. On organic affections and injuries of the spinal cord, producing some of the symptoms of spinal hemiplegia. Lancet 1869;93:1-3.

7. Koehler PJ. Brown-Séquard and cerebral localization as illustrated by his ideas on aphasia.J Hist Neurosci 1996;5:26-33.

8. York GK. Brown-Séquard's theory of recovery.J Hist Neurosci 1996;5:34-42.

9. Brown-Séquard CE. On localization of functions in the brain. Boston Med Surg J 1875;93:119-124. (Retrieved from: http://archive.org/ details/newenglandjourna93mass)

10. Brown-Séquard CE. Cerebral localization. Forum 1888;5:166-177. 